\title{
Analysis of different tracking intervals for Parabolic Trough Collectors for water disinfestation in agricultural applications
}

\author{
Análise de diferentes intervalos de rastreamento de Coletores \\ Solares Parabólicos para desinfestação de água em aplicações \\ agrícolas
}

\author{
Paulo Alexandre Costa Rocha ${ }^{1 *}$; Stéphano Praxedes Mendonça ${ }^{2}$; Thiago Taketaro \\ Guilherme Watanabe ${ }^{2}$; Maria Eugênia Vieira da Silva ${ }^{3}$; Ricardo José Pontes Lima ${ }^{4}$
}

\begin{abstract}
The use of renewable energy is growing every year as an alternative to fossil fuel technology. Solar energy presents itself as a good alternative due to its great availability and energy potential. Solar thermal energy uses heat to warm fluids, and can also generate electricity, as well as being used in industrial processes and water desalination. The research and use of Parabolic Trough Collectors (PTCs) has been growing in recent years due to their ability to heat fluids at high temperatures in a relatively small area. In this work, two small PTCs were manufactured and tests were performed to improve the arrangements in order to increase the absorbed energy to reach temperature values for water disinfestation, aiming at the control of phytopathogens to control soil pathogens in small and medium farms. To control the automatic tracker, a low-cost system with Arduino, Light Dependent Resistors (LDRs) and step motors was used. The tracking times intervals analyzed were 1,5 and 15 minutes. For the 1-minute tracking interval, the PTCs presented a thermal efficiency of $25.87 \%$, with temperatures between 45 and $70{ }^{\circ} \mathrm{C}$ and an average of $63.73{ }^{\circ} \mathrm{C}$. For the 5-minute tracking interval, the thermal efficiency was $18.48 \%$, reaching temperatures between 41 and $68{ }^{\circ} \mathrm{C}$ and an average of $57.9^{\circ} \mathrm{C}$. For the 15 -minute tracking interval, the PTCs presented a thermal efficiency of $14.80 \%$, with temperatures between 39 and $62{ }^{\circ} \mathrm{C}$ and an average of $51.88^{\circ} \mathrm{C}$. The results showed that the tracking intervals of 1 and 5 minutes present more values between the lethal temperature range of 45 and $60^{\circ} \mathrm{C}$ for phytopathogens. For agricultural application, the usage of a tracking interval of 5 minutes could be a good option for reducing the waste of system energy compared to the interval of 1 minute.
\end{abstract}

Key words: Parabolic Trough Collector. Solar energy. Solar Tracking. Water disinfestation.

\section{Resumo}

O uso de energia renovável está crescendo a cada ano como alternativa à tecnologia de combustíveis fósseis. A energia solar apresenta-se como uma boa alternativa devido à sua grande disponibilidade e potencial energético. A energia solar térmica utiliza o calor para aquecer os fluidos e também pode gerar eletricidade, bem como ser usada em processos industriais e dessalinização da água. A pesquisa

${ }^{1}$ Prof. Dr., Universidade Federal do Ceará, UFC, Departamento de Engenharia Mecânica, Fortaleza, CE, Brasil. E-mail: paulo. rocha@ufc.br

2 Pesquisadores, Mestres, UFC, Departamento de Engenharia Mecânica, Fortaleza, CE, Brasil. E-mail: stephano_praxedes@, hotmail.com; taketaro@outlook.com

${ }^{3}$ Profa ${ }^{a}$ PhD, UFC, Departamento de Engenharia Mecânica, Fortaleza, CE, Brasil. E-mail: eugenia@ufc.br

${ }^{4}$ Pesquisador, Dr., UFC, Departamento de Engenharia Mecânica, Fortaleza, CE, Brasil. E-mail: rjponteslima@gmail.com

"Author for correspondence 
e o uso de Coletores Solares Parabólicos (PTCs) têm crescido nos últimos anos devido à capacidade de aquecer fluidos em altas temperaturas em uma área relativamente pequena. Neste trabalho, dois pequenos PTCs foram fabricados, e testes foram realizados para melhorar os arranjos, a fim de aumentar a energia absorvida para atingir valores de temperatura para desinfestação de água, visando o controle de fitopatógenos no controle de patógenos de solo em pequenas e médias fazendas. Para controlar o rastreador automático foi utilizado um sistema de baixo custo com Arduino, Resistores de Potência Luminosa (LDRs) e motores de passo. Os intervalos de tempo de rastreamento analisados foram de $1,5 \mathrm{e}$ 15 minutos. Para o intervalo de rastreamento de 1 minuto, os PTCs apresentaram uma eficiência térmica de $25,87 \%$, com temperaturas entre 45 e $70^{\circ} \mathrm{C}$ e $63,73^{\circ} \mathrm{C}$ de temperatura média. Para o intervalo de rastreamento de 5 minutos, a eficiência térmica foi de $18,48 \%$, atingindo temperaturas entre 41 e $68^{\circ} \mathrm{C}$ e $57,9^{\circ} \mathrm{C}$ de temperatura média. Para o intervalo de rastreamento de 15 minutos, os PTCs apresentaram uma eficiência térmica de $14,80 \%$, com temperaturas entre 39 e $62^{\circ} \mathrm{C}$ e $51,88^{\circ} \mathrm{C}$ de temperatura média. Os resultados mostraram que os intervalos de rastreamento de 1 e 5 minutos apresentam mais valores entre a faixa de temperatura letal de 45 e $60^{\circ} \mathrm{C}$ para fitopatógenos. Para aplicações agrícolas, o uso de um intervalo de rastreamento de 5 minutos poderia ser uma boa alternativa para uma redução no desperdício da energia do sistema em comparação com o intervalo de 1 minuto.

Palavras-chave: Coletores Solares Parabólicos. Energia Solar. Rastreamento Solar. Desinfestação de água.

\section{Introduction}

A number of renewable energy resources exist to provide the needed shift from conventional fossil-based resources. These resources include geothermal, wind energy, bioenergy and solar energy (Mwesigye \& Meyer, 2017). The use of solar energy is one of the most important ways of solving problems such as global warming, fossil fuel depletion, and increasing energy demand (Liu, Zheng, Liu, \& Liu, 2019). Its use is basically divided between photovoltaic and thermal energy, employing photovoltaic panels and solar collectors, respectively.

The correct spatial orientation of such equipment may increase the intensity of the incident solar radiation flux, which depends on azimuth and inclination angles (Chang, 2009). Solar collectors are devices that absorb solar energy and heat a liquid or gaseous fluid for certain processes (Jebasingh \& Herbert, 2016).

There are numerous applications for solar thermal equipment. At low temperature levels, space heating and domestic hot water production are the most typical applications. At medium temperature levels, solar cooling, desalination and industrial process heat are applications that can exploit solar energy. At high temperature levels, concentrating solar power plants are the applications that attract the most attention worldwide. Moreover, for extremely high temperature levels up to $1000{ }^{\circ} \mathrm{C}$, processes such as hydrogen production and methanol reforming can utilize solar irradiation (Bellos, Tzivanidis, \& Antonopoulos, 2017).

Solar collectors can be used in seed thermotherapy as an alternative to the commonly used chemical treatments for the elimination of field and storage pathogens that may compromise their germination and vigor.

Farmers use mainly chemical treatments, despite their negative impacts on the environment and human health, as pests diminish the global potential crop yield by up to $40 \%$ (Ghatrehsamani et al., 2019). The use of herbicides should be as limited and as efficient as possible in order to eliminate the negative environmental impacts (Partel, Kakarla, \& Ampatzidis, 2019). There are more sustainable pathogen control methods, such as by using solar energy technologies, to reduce the negative impacts of pesticides.

Thermotherapy is one nonchemical method for controlling pests and diseases. It can be implemented through different methods such as soaking the 
treated material in hot water or hot solution, hot air, using vaporized water or vaporized solution, and with the use of microwave energy (Bahlol, Sinha, Hoheisel, Ehsani, \& Khot, 2018).

This type of treatment is based on the concept that heating a plant at a specific time and temperature can kill temperature-sensitive pests and pathogens with the minimum impact on the host (Ghatrehsamani et al., 2019). Most phytopathogenic microorganisms present a lethal thermal point at temperatures in the range of 45 to $60^{\circ} \mathrm{C}$ (Cochrane, 1958; Wolf \& Wolf, 1947).

Genetic, physical, physiological and sanitary factors influence the quality of the stored seeds and their subsequent performance in the field (Marcos, 2005). Storage allows the maintenance of the physiological quality of the seeds, which can be preserved under favorable conservation conditions, prior to sowing (Carvalho \& Nakagawa, 2012; Santos, Menezes, \& Vilell, 2005).

Relative humidity and temperature influence fungal activity in storage. In situations favorable to the development of pathogens, it is necessary to use a sanitary treatment (Schneider, Gusatto, Malavasi, Stangarlin, \& Malavasi, 2015).

A solar collector was developed by Embrapa Environment and Agronomic Institute of Campinas (Division of Agricultural Engineering) in 1991 to disinfect substrates used in containers in plant nurseries. Compared to other traditional systems of disinfestation, the equipment presents several advantages because it is not a chemical method. It presents no risks to the operator, does not release residues and does not pollute the environment. The use of the collector allows the survival of beneficial thermotolerant microorganisms that prevent reinfestation by the pathogen, which does not occur in the methyl bromide treatments and autoclaves that sterilize the soil, creating a "biological vacuum" (Ghini, 2004).

As in thermal treatments for storage, solar collectors can be used on irrigation water from plantations. Once installed in the soil or in the crop, the control of these pathogens is usually difficult and requires the use of chemicals that, in addition to costing production, are not always effective and may lead to contamination of the water sources. For this reason, preventive methods that are capable of eliminating or reducing the quantity of propagules in water should be adopted (Tanaka, Ito, Braga, \& Armond, 2003). Braga et al. (2001) and Tanaka et al. (2003) analyzed an automated system of solar heating by flat collectors to control phytopathogens in irrigation water. The results showed better thermal yields than in conventional systems, making it a low-cost option for use in nurseries, greenhouses and small or medium-sized farms.

There are several ways to improve the system efficiency of these devices, for example, by concentrating solar radiation through the reflectors' geometry, as occurs in parabolic or conic collectors. Other methods are to use selective surfaces on absorb tubes, nanofluids instead of conventional thermic fluids, and tracking systems (Behar, Khellaf, \& Mohammedi, 2015; Jebasingh \& Herbert, 2016).

The Parabolic Trough Collector (PTC) consists of mirrors mounted on the supporting structure to reflect and concentrate the solar radiation to its focus in order to achieve the required temperature. These supports may be made of steel, aluminum, or other material with higher strength. A PTC is described as a long, trough-shaped reflector that has a parabolic cross-section. The mirrors focus the reflected sunlight radiation along a line running the length of the trough. In order to collect this heat, a pipe, called a receiver, is positioned along the length of the PTC at its focus and a heat collection fluid is pumped through it (Hafez et al., 2018).

PTCs are lightweight, low-cost structures and are used for process heat applications between 50 ${ }^{\circ} \mathrm{C}$ and $400{ }^{\circ} \mathrm{C}$. The performance of the collector, which depends on the design conditions and the type of materials used, is significantly affected by factors such as the reflectivity and the absorption capacity 
of the receiver, the type and the operating conditions of the heat transfer fluid, and the mechanism of tracking (Erdogan, Colpan, \& Cakici, 2017).

The best way to collect more energy is by using the tracking system, which aims to decrease the incident solar angle. In general, the benefits of tracked photovoltaic panels are $20-40 \%$ greater than non-tracked (Chang, 2009). In the case of solar concentrators, the tracking is essential, since the geometry is developed for the use of beam solar radiation, but it is also a disadvantage. The need for moving parts in the tracking system results in a relatively high maintenance cost (Hafez et al., 2018).

Basically, there are two types of tracking systems: single-axis and dual-axis. They usually work using an electric energy mechanism (active tracking) or a thermic mechanism (passive tracking) (Li, Liu, \& Tang, 2010). The single-axis tracking collectors are orientated on a North-South axis and tracked on an East-West axis. The second category has two tracking axes that move perpendicularly to each other (Suman, Khan, \& Pathak, 2015).

Single-axis tracking is most commonly used in PTC, because of the low cost in relation to dualaxis, which is a more complex project, increasing the pipe fittings, thermal losses and maintenance costs (Behar et al., 2015).

Abdallah (2004) analyzed the effect of the use of different types of tracking systems in electric power generation by photovoltaic panels and concluded that the gains are up to $43.87 \%, 37.53 \%$ and $15.69 \%$ in dual-axis tracking, East-West tracking and North-South tracking, respectively, compared to a fixed inclined surface of $32^{\circ}$ in the south of Jordan. Sungur (2009) reported a similar result, with an improvement of $42.6 \%$ in energy gains obtained by a dual-axis tracking system in Turkey. Similarly, Chang (2009) concluded that the annual gain obtained by a North-South tracking system is much lower than by an East-West tracking.

Mousazadeh et al. (2009) in their studies concluded that the energy improvement lies between $10 \%$ and $100 \%$, depending on the time of year and the geographic conditions, where energy consumption by trackers is $2 \%$ to $3 \%$ of the generated energy.

In cloudy regions, the annual energy improvement by trackers can be up to $20 \%$. In general, it can be from $30 \%$ to $40 \%$ in areas with good irradiation conditions (Mousazadeh et al., 2009). Barbosa (2009) developed a low-cost PTC tracking system. He used a microcontroller and a Light Dependent Resistor (LDR) to perform the tracking, obtaining satisfactory results. In the same way, Afrin, Titirsha, Sanjidah, Siddique and Rabbani (2013) used these instruments in a dual-axis tracking system and concluded that the efficiency of a solar panel can be improved by $50-60 \%$, controlling the actuators step-by-step.

Othman, Manan, Othman and Junid (2013) used a microcontroller in an Arduino platform to control a servo motor, in order to analyze the system efficiency of a dual-axis tracking. The system contained two servo motors to move a solar panel to a direction with higher luminous intensity, which was detected by five LDRs.

Bentaher et al. (2013) designed and built a simple tracking system using LDRs. The system accuracy was calculated, and the optimum angle between two LDRs was optimized numerically and experimentally.

Rizvi, Addoweesh, El-Leathy and Al-Ansary (2014) proposed an algorithm, in situations where high accuracy is not needed, to calculate the position of the sun for tracking without the use of sensors, this being considered energetically efficient, showing an efficiency improvement of $49 \%$ compared to nontracking systems.

Ali, Zanzinger, Debose and Stephens, (2016) created a low-cost data collector using the Arduino platform, temperature, luminous intensity, proximity, $\mathrm{CO}_{2}$ concentration sensors and voltage data collector. The system presented similar results 
to commercial products.

The use of gradual tracking rather than continuous tracking keeps actuators inactive for most of the time, saving energy in the process. Baltas, Tortoreli and Russel (1986) did a comparative study between the effects of continuous and step-by-step tracking. They showed that, in continuous tracking, up to $99.7 \%$ of solar radiation can be received by a photovoltaic panel array if the system rotates $7.5^{\circ}$ every half hour.

According to Konar and Mandal (1991), for $n$-step tracking, the " $n$ " can be determined experimentally by some energy gain criteria. The tracking system has to be by $n$ steps, if the extra energy collected on the $n$th step is higher than the consumed energy by the tracking device for the $n$th positioning.

Huang and Sun (2007) designed an EastWest single-axis tracking system, adjusting the photovoltaic panel slope in three fixed angles by day. It was found that the ideal panel angle during the morning and afternoon is about $50^{\circ}$ to the vertical, independent of latitude, with a gain of $24.5 \%$ in power generation compared to a fixed system for geographic latitude below $50^{\circ}$.

Li et al. (2010) analyzed the optical performance of Inclined South-North (ISN) single-axis tracked solar panels and concluded that the maximum annual radiation incident was about $96-97 \%$ compared to dual-axis tracking for most areas in China with abundant solar resources.

Malav and Vadhera (2015) used a single-axis tracking system that implements a control algorithm to move the panel in both directions, reducing consumption by using a step-by-step tracking that is turned on at time intervals compared to the conventional system.

The $n$ steps tracking has been analyzed until now for its applicability in energy generation by photovoltaic panels, in order to dispense with the continuous tracking and to reduce the energy costs due to the tracking system. In these cases, it is optional to require a prior study to analyze the cost-benefit of its use, because the control and actuation systems considerably increase the project cost. In the case of solar concentrators, both for power generation and for only heating fluids, the tracking system becomes indispensable, since they are designed to capture solar beam radiation. In this way, the energy saving of a tracking system allows the reduction of project operating costs, which are essentially inevitable.

In this paper, Arduino platform microcontrollers were applied, which in recent years have been recognized as an interesting alternative, due to their low cost, for tracking systems applicable for solar concentrators in agricultural areas for water disinfestation. LDR sensors were used to measure the luminosity and step motors to move the PTCs. The influence of the time between the $n$ steps tracking intervals was analyzed in relation to the energy absorbed by the collector. The objective was to find the optimum time for the difference between the energy obtained by the continuous tracking and by the $n$ steps tracking to be as small as possible in order to promote reduced energy costs without significant losses in absorbed energy.

\section{Materials and Methods}

Arduino is a microcontroller that enables the use of electronic components such as motors, LEDs, sensors and others. It is an open prototyping platform. For these reasons, Arduino is a very widespread option for simple use in scientific experiments in various areas such as physics, chemistry and engineering (Ali et al., 2016). Arduino Uno (Figure 1) is a board that has a microcontroller model ATmega328P and 14 digital outputs/inputs, 6 of which can be used as PWM outputs, 6 analog inputs, $16 \mathrm{MHz}$ quartz crystal, USB connection and an external source input. The input voltage can lie between 7 and $12 \mathrm{~V}$. 


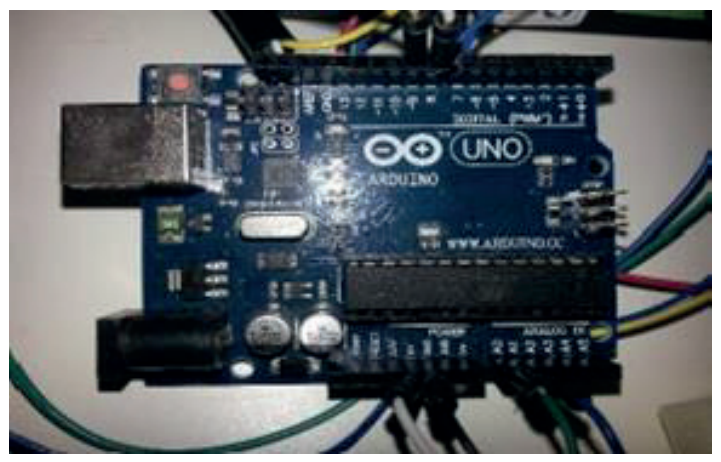

Figure 1. Arduino Uno.

Light Dependent Resistors or LDRs (Figure 2) are electrical resistors that vary depending on the incident light intensity on a photosensitive surface. The resistance variation can reach $100 M \Omega$ in the dark and $100 \Omega$ when directly illuminated (Barbosa,
2009; Moraes, 2012; Lima, 2014). The advantage of using this device is the low-cost and the fact that it has a voltage signal in the microcontroller magnitude order.

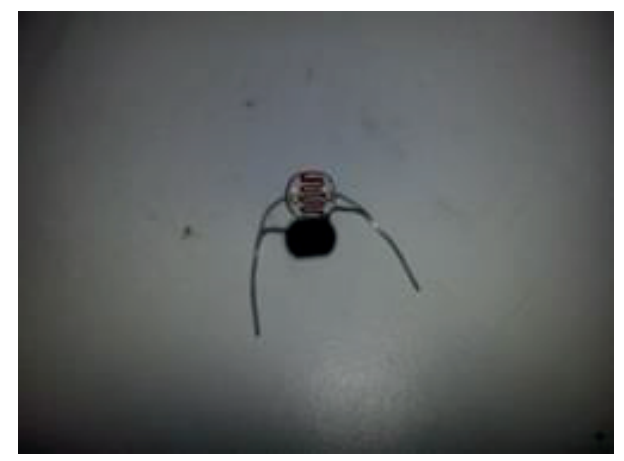

Figure 2. LDR sensor.

To perform the tests, arrangements of two parabolic solar collectors were built. They were made of a 1020 steel plate with the dimensions of 1

$$
y=\frac{x^{2}}{0.6}
$$

There are some parameters for the reflective parabola construction that are also important, such as the geometric concentration rate, acceptance angle and edge angle. The most important is the first of these, and it represents the collector opening area fraction in relation to the receiver area, a $\mathrm{mm} \times 689 \mathrm{~mm} \times 1000 \mathrm{~mm}$, and its curvature obeys Equation (1). relationship described in Equation (2). Applying the Second Law of Thermodynamics for the heat exchange between the sun and the receiver, the maximum possible concentration rate for parabolic collectors is in the order of 212 (Behar et al., 2015). 


$$
C=\frac{A_{a}}{A_{r}}
$$

in which $A_{a}$ is the concentrator aperture area, $A_{r}$ is the receiver superficial area and $C$ is the concentration rate. The second parameter is the acceptance angle, which is the angular range under which all solar beam rays that are reflected by the parabolic reflector reach the absorber tube without

$$
\sin \theta_{x}=\frac{D_{a b s o}}{2 f_{P T C}\left(1+\frac{y}{2 f_{P T C}}\right)^{2}}
$$

The edge angle $\left(\phi_{R}\right)$, calculated by Equation (4), and to the collector opening length (Goswami \& is related to the arc length, to the focal length $(f)$, Kreith, 2008; Behar et al., 2015).

$$
\tan \frac{\phi_{R}}{2}=\frac{A_{a}}{4 f}
$$

The concentration rate of the collectors used is 15 , which means that 15 suns are concentrated in the absorber. The minimum acceptance angle is $0.53^{\circ}$, and the edge angle should be between $70^{\circ}$ and $110^{\circ}$ (Macedo-Valencia, Ramírez-Ávila, Acosta, Jaramillo, \& Aguilar, 2014). The collector parameters used are shown in Table 1.

Table 1

PTCs' parameters

\begin{tabular}{cc}
\hline Description & Dimensions \\
\hline Opening length & $600 \mathrm{~mm}$ \\
Parabola length & $1000 \mathrm{~mm}$ \\
Focal distance & $150 \mathrm{~mm}$ \\
Parabola radius & $300 \mathrm{~mm}$ \\
Absorber diameter & $12.7 \mathrm{~mm}$ \\
Concentration rate & 15 \\
Acceptance angle & $1.21^{\circ}$ \\
Edge angle & $82.87^{\circ}$ \\
\hline
\end{tabular}

Two shapes were welded at two opposite lateral ends, with holes (diameters $12.7 \mathrm{~mm}$ ) at the parabola focus, in order to receive the absorber tube, as can be seen in Figure 3, and two other holes (diameters
$24 \mathrm{~mm}$ ) in the center of mass. A complete view of the system can be seen in Figure 4. Using two identical parabolic collectors, it was possible to carry out tests to compare the improvements. 


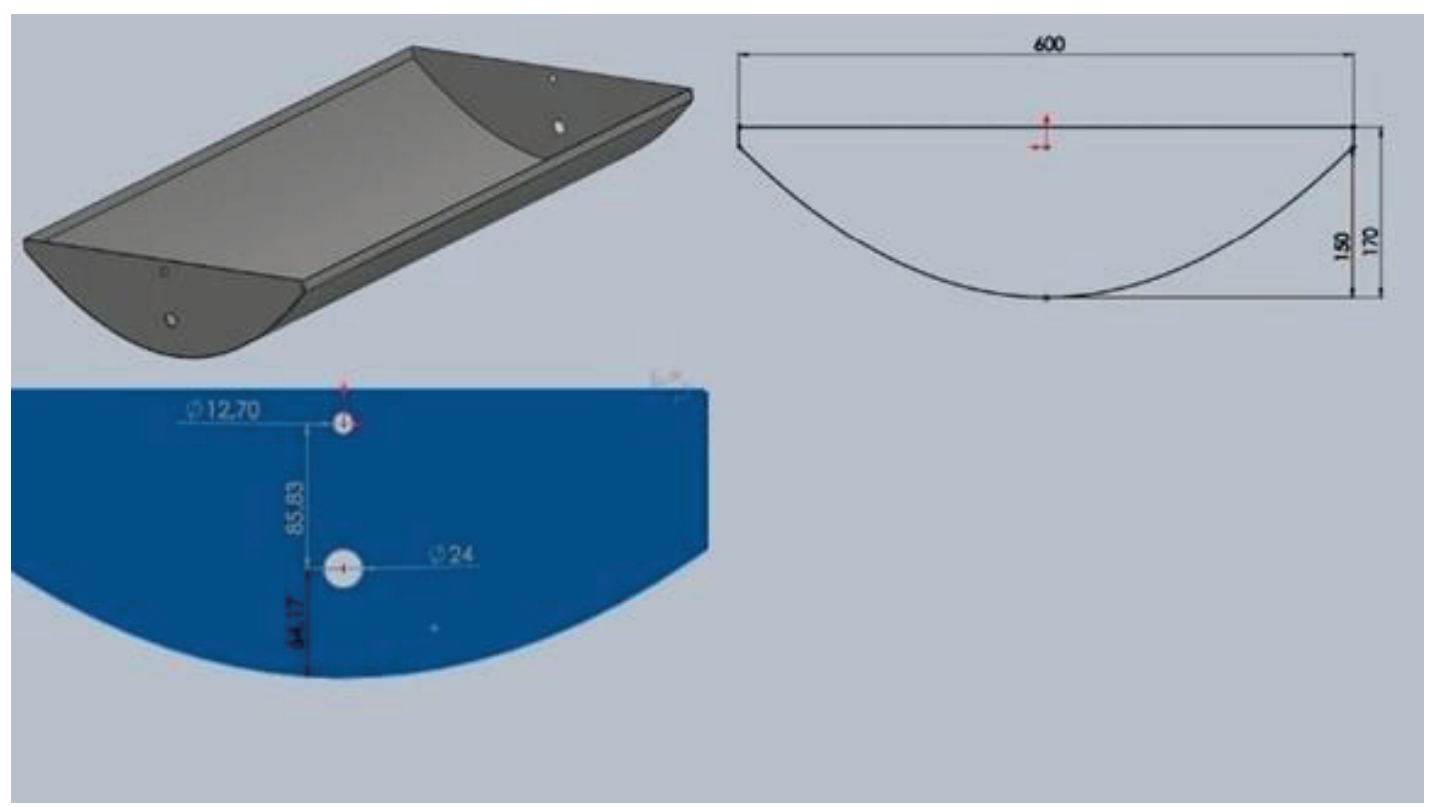

Figure 3. Parabolic reflector.

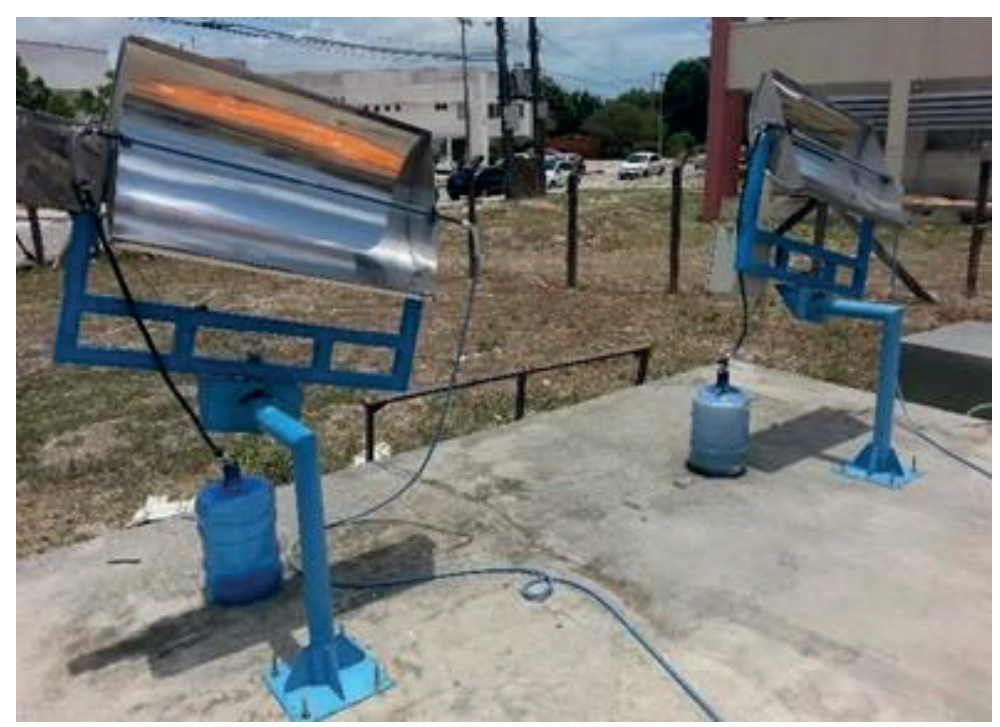

Figure 4. Parabolic Trough Collectors installed.

It is possible to perform a manual adjustment of the solar declination angle calculated by Equation (5). The declination was calculated for the correct system orientation in order to maximize the energy gain. The adjustment is made by loosening and then tightening a hexagonal bolt.

$$
\delta=23,45 \sin \left(360 \frac{284+n}{365}\right)
$$

where $n$ is the day of the year. 
Copper absorber tubes, $12.7 \mathrm{~mm}$ in diameter, were used for each PTC. These tubes were coated with high-temperature black matte spray paint in order to increase their heat absorption efficiency. Part of the optimization of the collectors was to place a steel mirror plate on the reflectors in order to increase the irradiation reflection: also, to reduce the convection loss, glass tubes were wrapped around the absorbers sealed with thermal insulation foam, as shown in Figure 5.

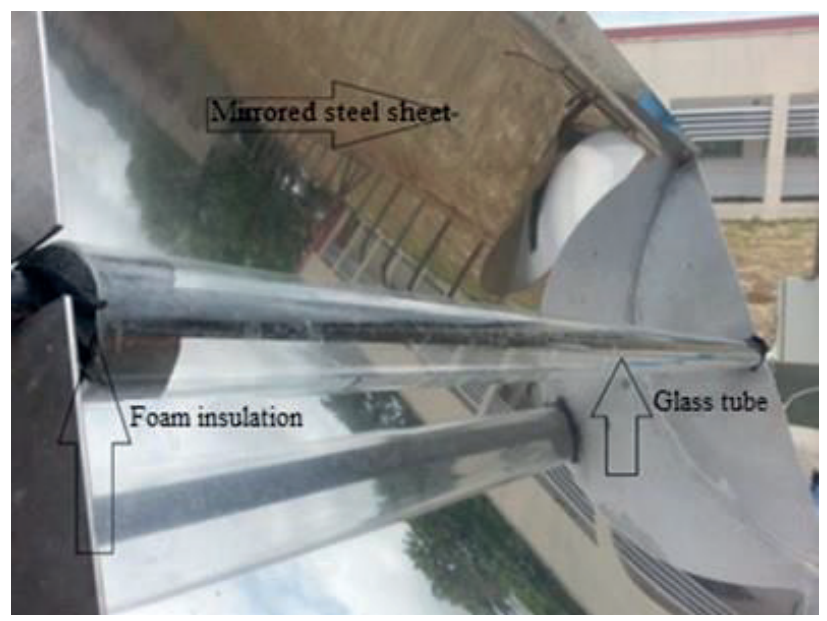

Figure 5. Mirrored steel sheet, glass tube and foam insulation.

A solar tracking system was then implemented with one Arduino board and two LDRs with a bulkhead to create a light barrier between them, as shown in Figure 6.

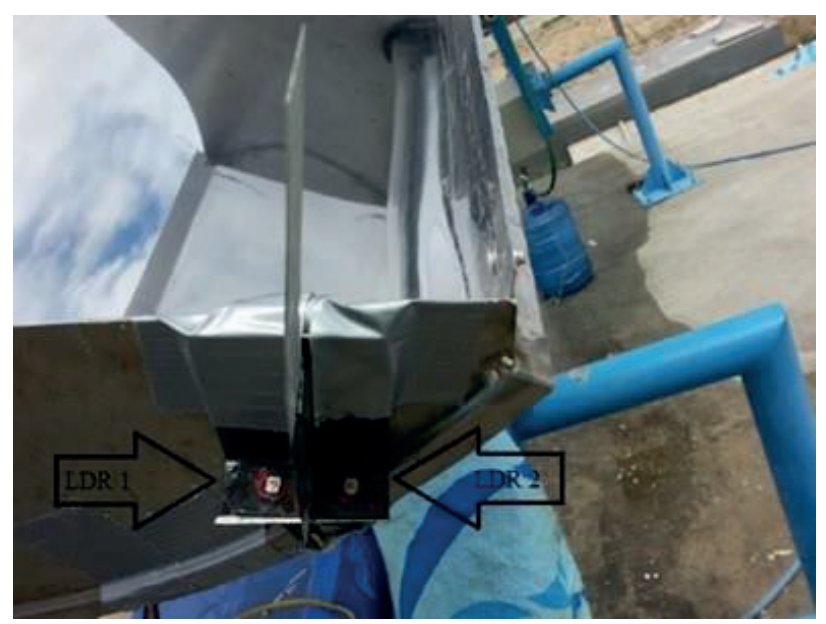

Figure 6. Disposition of LDRs for tracking.

This bulkhead allows a difference in the LDRs luminance values provided to the Arduino board. The result should be less than a certain calibration value, which was determined experimentally. When the motor is started, the collector rotates until the difference between the two LDRs values is within an interval found when performing the calibration. This is done by submitting the LDRs to different conditions necessary for the tracking:

i. East-West Tracking: the difference obtained between LDRs 1 (West) and 2 (East) in a shadowing situation of the LDR 2 is recorded; 
ii. West-East Tracking: the difference obtained between LDRs 1 (West) and 2 (East) is recorded in a LDR 1 shadowing situation;

iii. No actuation: the value of the difference obtained between LDRs 1 (West) and 2 (East) in high and low luminous conditions in both sensors is recorded.

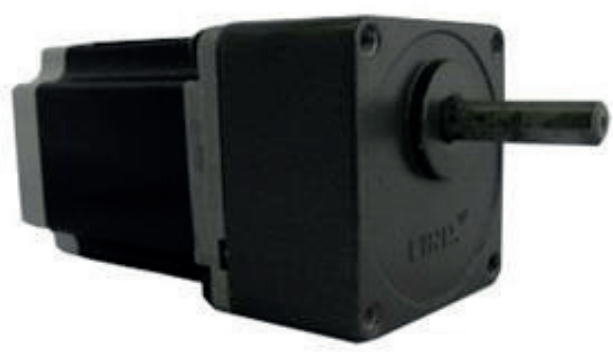

(a)

Figure 7. (a) Step motor. (b) Driver.

The water flow through the absorber was around 60-64 $\mathrm{mL} \mathrm{min} \mathrm{m}^{-1}$. The temperature was measured at the collector inlet and outlet with Omega K-type thermocouples connected to a RDXL12SD datalogger of the same manufacturer.

In the first set of tests, it was necessary to make a statistical comparison between Collectors 1 and 2 to know if, subjected to the same climatic conditions, they would obtain the same experimental results. Thus, in experiment 1 , the systems were manually oriented every 15 minutes.
A pre-dimensioned NEMA 23 - $200 \mathrm{kgf.cm} / 3 \mathrm{~A}$ Linix step motor with a reduction box and a Neoyama AKDMP16- $.2 A$ driver, shown in Figure 7 , were used to rotate the collector.

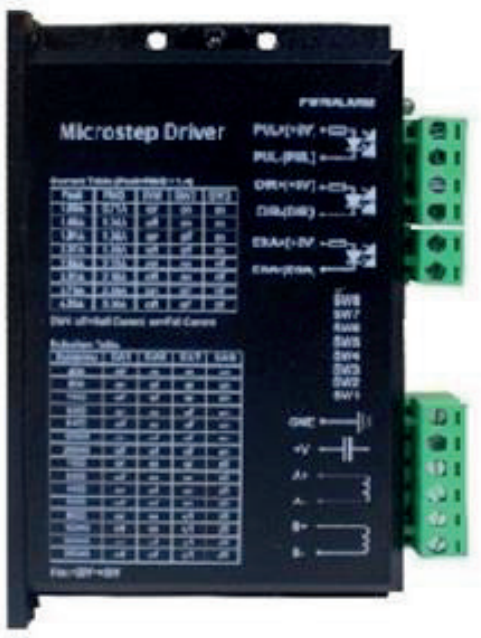

(b)

In experiment 2, validation of the tracking system was carried out in order to analyze the precision and the similarity of the results obtained by manual tracking of experiment 1 .

The following experiments then analyzed the influence of the tracking interval on the collectors' energy absorption. In experiment 3, Collector 1 was set to a 1 minute interval and Collector 2 was set to 5 minutes. In experiment 4 , Collector 1 was again set to 1 minute and Collector 2 was set to 15 minutes. In experiment 5, Collector 1 was set to an interval of 5 minutes and Collector 2 was set to 15 minutes (Table 2). 
Table 2

Experiments tracking time in minutes

\begin{tabular}{ccc}
\hline Experiments & Collector 1 & Collector 2 \\
\hline 1 & $15^{\prime}$ & $15^{\prime}$ \\
2 & $15^{\prime}$ & $15^{\prime}$ \\
3 & 1, & 5 \\
4 & 1, & $15^{\prime}$ \\
5 & 5, & $15^{\prime}$ \\
\hline
\end{tabular}

To perform a comparative evaluation of the experiments, we attempted an Analysis of Variance (ANOVA), which identifies whether a set of samples are statistically different from each other. For these analyses, the water energy gain was calculated through Equation (6).

$$
\dot{Q}=\dot{m} \cdot c_{P} \cdot \Delta T
$$

For the energy calculations, the fluid density of $1000 \mathrm{~kg} \mathrm{~m}^{-3}$ was used, the volume flow rate was $62 \mathrm{~mL} \mathrm{~min}^{-1}$ and $c_{p}=4.182 \mathrm{~kJ} \mathrm{~kg}^{-1} \mathrm{~K}^{-1}$. The water temperature values were acquired through thermocouple measurements at the absorber inlet and outlet of each solar collector. With these data, two populations of energy samples from Collectors 1 and 2 were acquired for each experiment.

To verify if it was possible to perform an ANOVA of the samples, it was necessary to find if they were normalized, so a normality test was done and the asymmetry and kurtosis measurements were observed. These values should lie between 3 and -3 for the samples to be considered as following a normal distribution (Montgomery \& Runger, 2007).

Normality tests are used to determine whether a data set can be modeled by a normal distribution. The symmetry and kurtosis tests can be used to validate the use of analysis of variance or any test that supposes a normal population (Montgomery \& Runger, 2007; Doria, 1999).

An analysis of variance table for each experiment was created. The null hypothesis is that there is no difference between the energy absorbed by Collectors 1 and 2. When the "critical F" is smaller than the "F", the null hypothesis is rejected. Then, it can be stated that the samples are different from each other and that Collector 1, under the tested conditions, is better than 2 with a $95 \%$ confidence level.

The ANOVA will indicate the probability that the null hypothesis is true, that is, the probability that no difference between the means exists between the studied groups, otherwise there will be a difference between them (Doria, 1999).

In the tests performed, it was not always clear to see from the temperature charts which one was the best arrangement. Therefore, this analysis was carried out with the initial hypothesis that the two collectors had the same energy performance. In this sense, once it is refused, it would be possible to corroborate what could be seen in the graphics, where the measurements were different one from each other and one arrangement would be better than the other.

\section{Results and Discussion}

Experiment 1 was to analyze if there exists any significant difference between the collectors under the same conditions, so both were rotated manually every 15 minutes. The inlet and outlet temperature 
results and solar radiation are shown in Figure 8. This made it possible to evaluate the performance when both arrangements were focused or not, for several cycles during a day.
Tables 3 and 4 present a statistical summary and ANOVA results, respectively, of the absorbed energy in $J s^{-1}$. The kurtosis and asymmetry are within the values that validate the ANOVA.

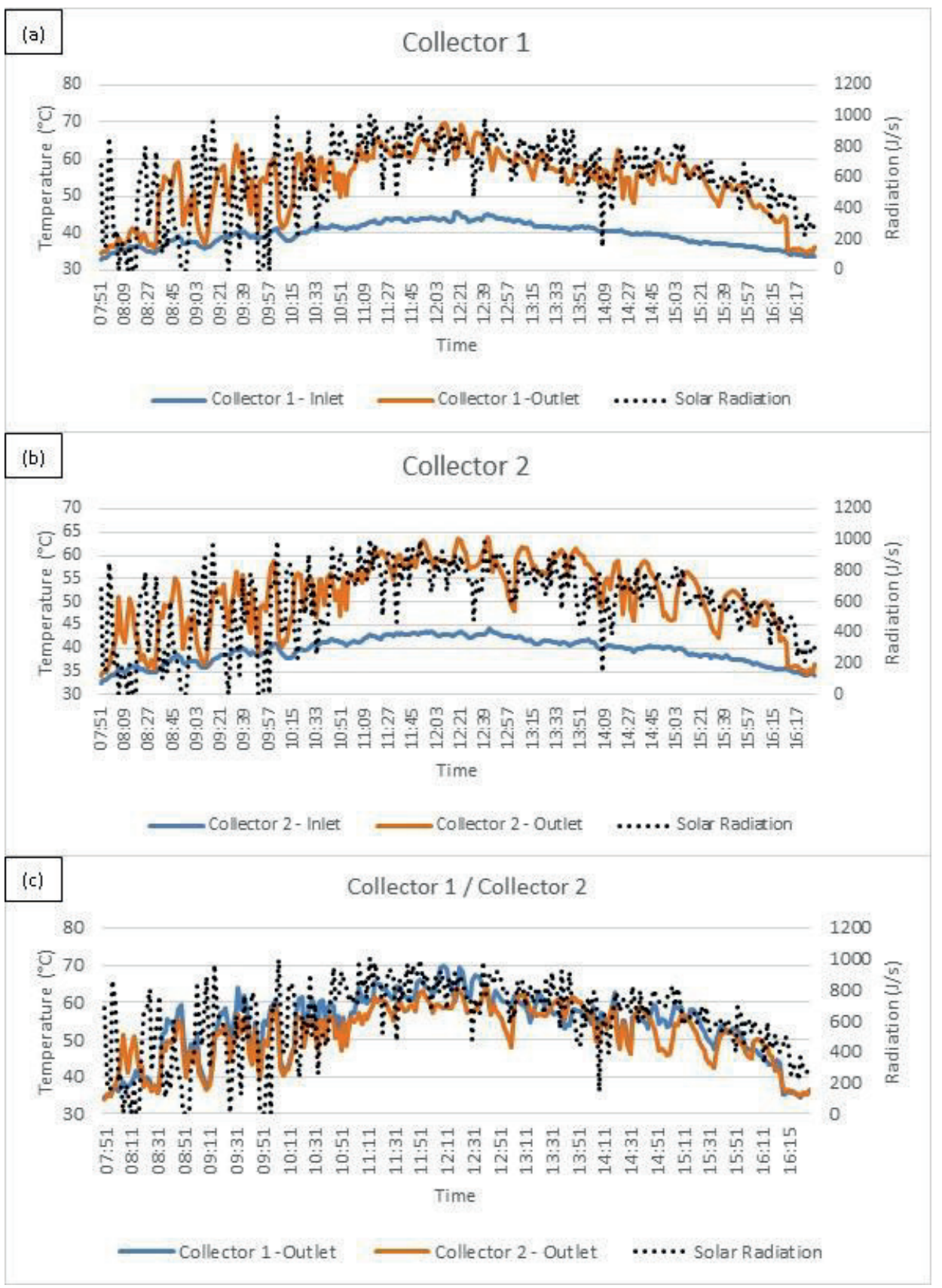

Figure 8. Results of experiment 1: (a) Collector 1 data; (b) Collector 2 data; (c) Comparison of collector outlet temperatures. 
Table 3

\section{Statistical data of experiment 1}

\begin{tabular}{lcc}
\hline Statistical study & Collector 1 & Collector 2 \\
\hline Average & 60.71 & 51.84 \\
Median & 67.91 & 58.83 \\
Default error & 1.66 & 1.41 \\
Mode & 68.78 & 64.88 \\
Standard deviation & 27.20 & 23.20 \\
Sample variance & 740.02 & 538.37 \\
Kurtosis & -0.39 & -0.61 \\
Asymmetry & -0.70 & -0.63 \\
\hline
\end{tabular}

Table 4

ANOVA of experiment 1

\begin{tabular}{ccccccc}
\hline Variation Source & SQ & gl & MQ & F & value-P & Critical F \\
\hline Between groups & 10585.30 & 1.00 & 10585.30 & 16.56 & 0.00 & 3.86 \\
Within the groups & 342608.88 & 536.00 & 639.20 & & & \\
Total & 353194.18 & 537.00 & & & & \\
\hline
\end{tabular}

Analyzing these tables, it can be concluded that there was a difference in samples, although the collectors were in the same conditions. This may be because there are some construction differences between them, so the collectors are not perfectly identical, which causes a difference in the energy absorption.

By analyzing the statistical results presented in Tables 3 and 4, it can be concluded that Collector 1 presents slightly better results than Collector
2, although it was developed under the same construction parameters. With this in mind, a statistical correction factor was applied in order to compare the energy absorption results of the next experiments. By a linear regression, as shown in Figure 9, it can be seen that there is a relation between the data of Collector 1 and Collector 2 . The value of 0.8224 was then used as a correction (calibration) factor in the following experiments.

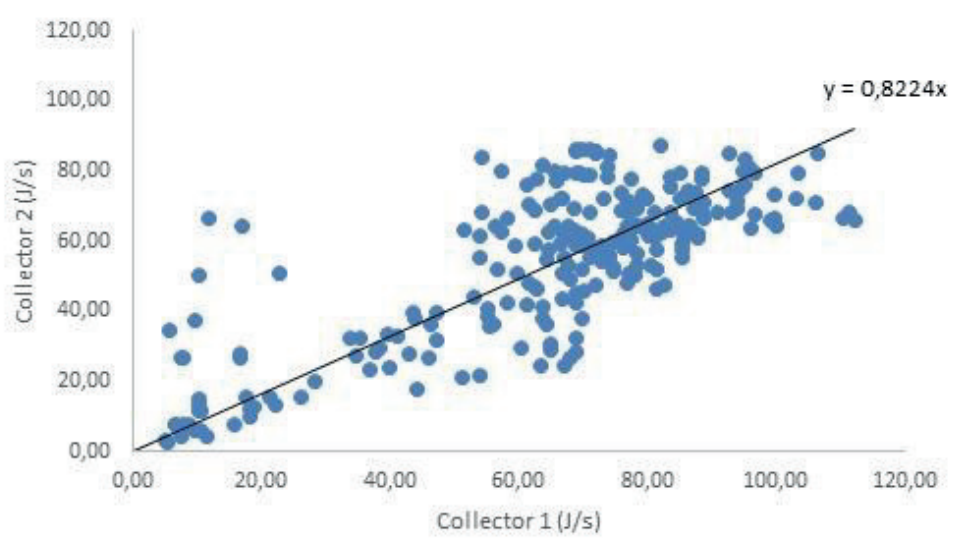

Figure 9. Comparison of absorbed energy results in experiment 1. 
In experiment 2, Collector 1 was automated and rotated every 15 minutes, as well as Collector 2, but in this case, manually. Similarly to experiment 1 , the output temperature performance for the two collectors can be observed in Figure 10(c), and, as shown by statistical analysis in Tables 5 and 6 , there is a difference between the samples. In Figure 11, it is possible to visualize that the points are uniformly distributed around the "equal performance" line (y $=\mathrm{x})$. However, there is an operational problem in rotating the collector manually, since it would be necessary to have a person available in unhealthy conditions of high insolation.

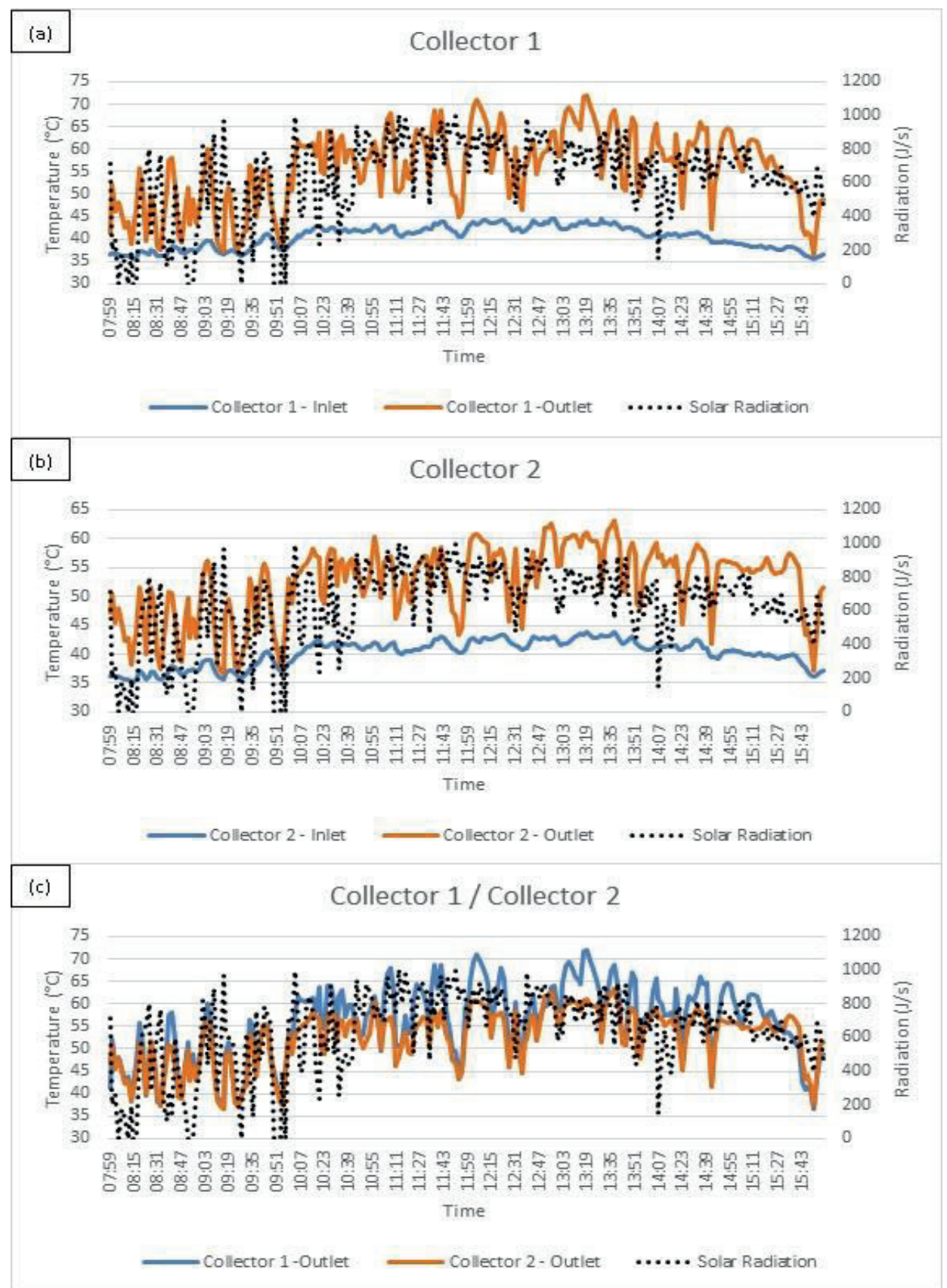

Figure 10. Results of experiment 2: (a) Collector 1 data; (b) Collector 2 data; (c) Comparison of collector outlet temperatures. 


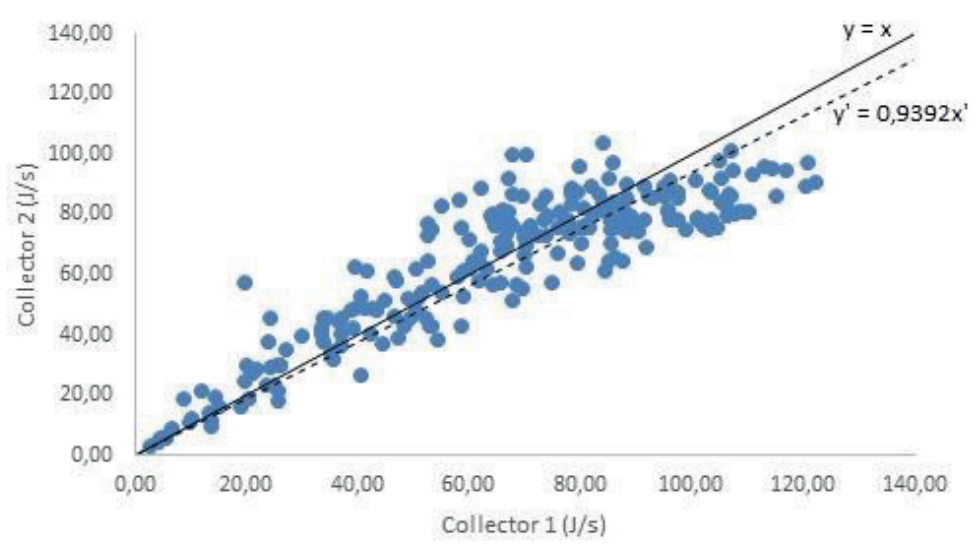

Figure 11. Comparison of absorbed energy results in experiment 2.

Table 5

Statistical data of experiment 2

\begin{tabular}{ccc}
\hline Statistical study & Collector 1 & Collector 2 \\
\hline Average & 66.03 & 64.59 \\
Default error & 1.90 & 1.57 \\
Median & 69.64 & 74.95 \\
Mode & 88.24 & 78.89 \\
Standard deviation & 29.39 & 24.39 \\
Sample variance & 863.82 & 595.09 \\
Kurtosis & -0.72 & -0.25 \\
Asymmetry & -0.36 & -0.83 \\
\hline
\end{tabular}

Table 6

ANOVA of experiment 2

\begin{tabular}{ccccccc}
\hline Variation Source & $\boldsymbol{S Q}$ & $\boldsymbol{g l}$ & $\boldsymbol{M Q}$ & $\boldsymbol{F}$ & value-P & Critical $\boldsymbol{F}$ \\
\hline Between groups & 249.46 & 1.00 & 249.46 & 0.34 & 0.56 & 3.86 \\
Within the groups & 348680.56 & 478.00 & 729.46 & & & \\
$\quad$ Total & 348930.02 & 479.00 & & & & \\
\hline
\end{tabular}

The purpose of the following tests was to evaluate the ideal automation time. With this in mind, and based on experiment 2, both collectors started to automatically track the Sun in experiment 3. In this case specifically, Collector 1 was programmed to track every 1 minute, while Collector 2 every 5 minutes.
It can be seen that Collector 1 presents better results than Collector 2, as observed in Figures 12 and 13 , where practically all points are below the collectors' equal performance line. This could be proven by the statistical results presented in Tables 7 and 8. 
Table 7

Statistical data of experiment 3

\begin{tabular}{ccc}
\hline Statistical study & Collector 1 & Collector 2 \\
\hline Average & 93.28 & 40.78 \\
Default error & 1.79 & 1.58 \\
Median & 102.08 & 44.97 \\
Mode & 108.57 & 54.17 \\
Standard deviation & 22.77 & 20.11 \\
Sample variance & 518.68 & 404.27 \\
Kurtosis & 2.75 & -1.38 \\
Asymmetry & -1.67 & -0.16 \\
\hline
\end{tabular}

Table 8

ANOVA of experiment 3

\begin{tabular}{ccccccc}
\hline Variation Source & $\boldsymbol{S Q}$ & $\boldsymbol{g l}$ & $\boldsymbol{M Q}$ & $\boldsymbol{F}$ & value-P & Critical $\boldsymbol{F}$ \\
\hline Between groups & 223286.03 & 1.00 & 223286.03 & 483.85 & 0.00 & 3.87 \\
Within the groups & 148595.89 & 322.00 & 461.48 & & & \\
Total & 371881.91 & 323.00 & & & & \\
\hline
\end{tabular}

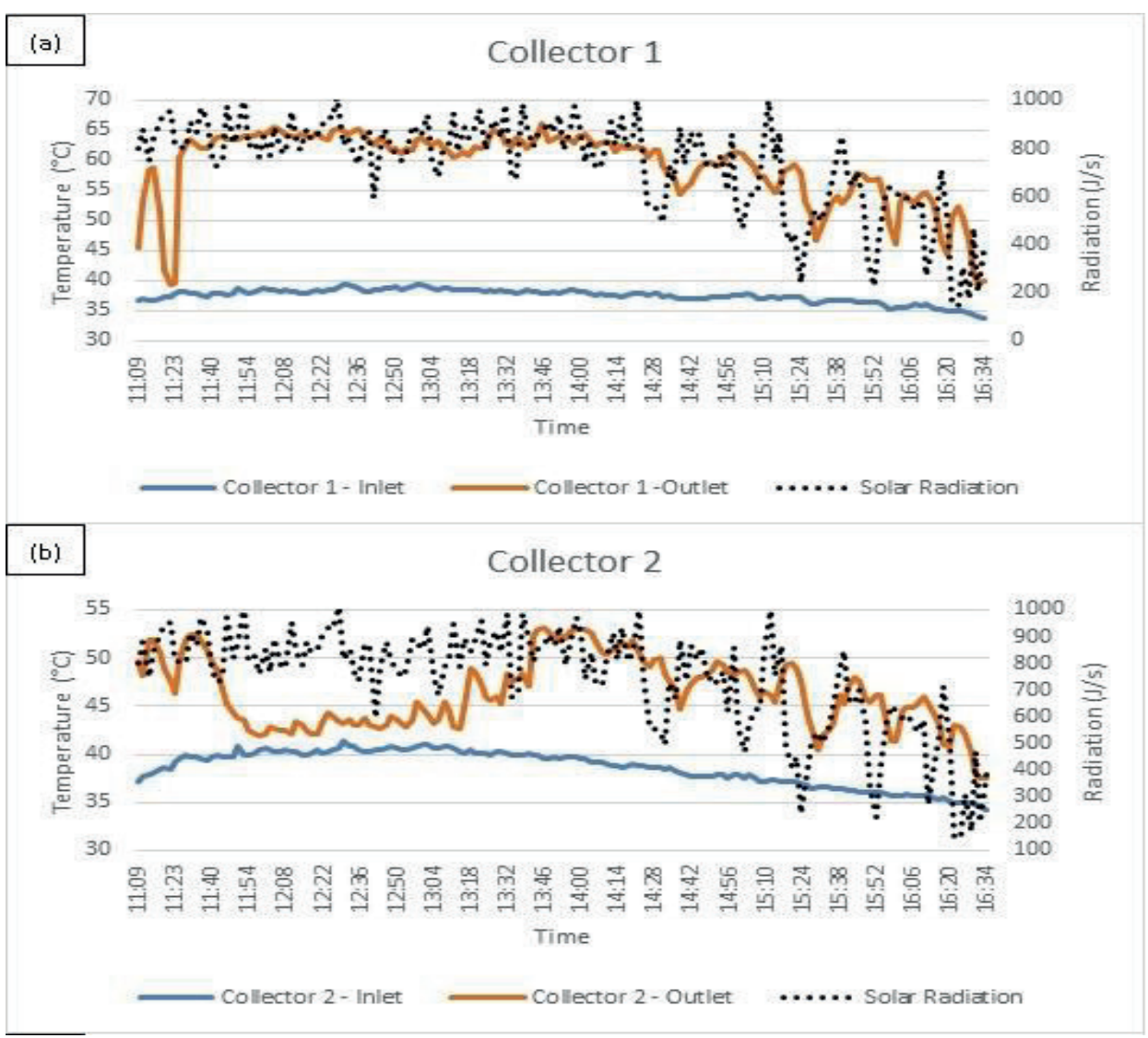




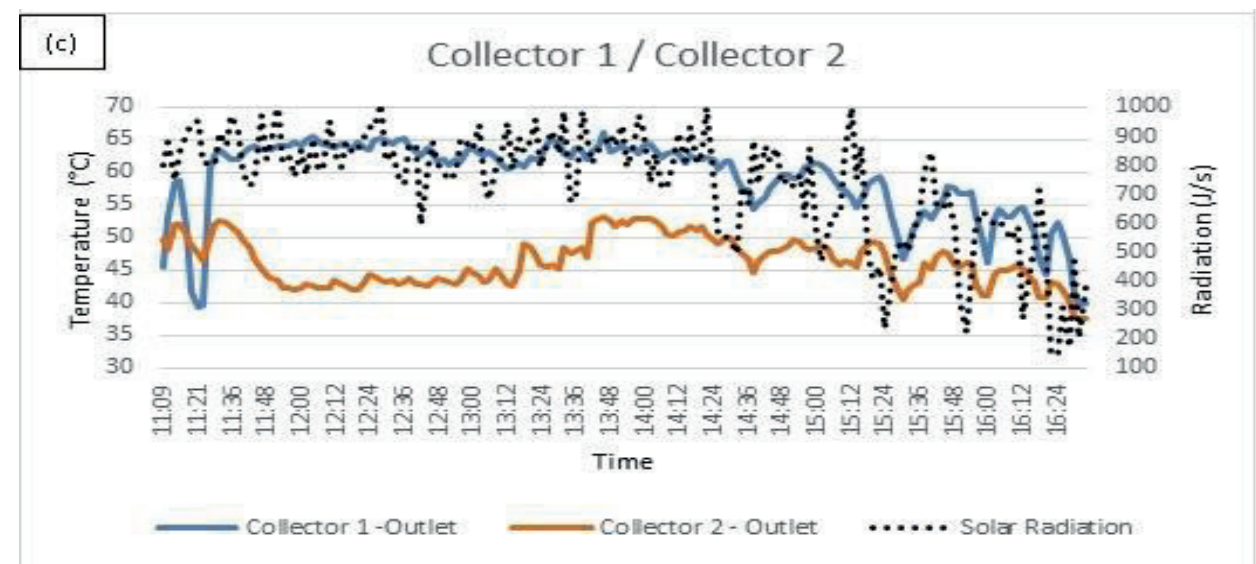

Figure 12. Results of experiment 3: (a) Collector 1 data; (b) Collector 2 data; (c) Comparison of collector outlet temperatures.

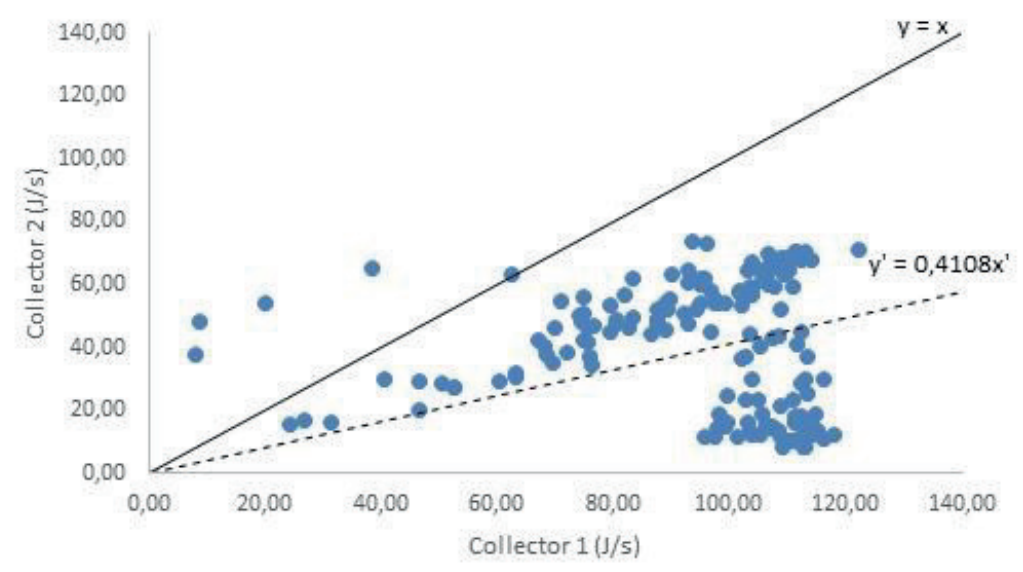

Figure 13. Comparison of absorbed energy results in experiment 3.

In experiment 4, Collector 1's rotation period was kept at 1 minute and for Collector 2 it was increased to 15 minutes. The statistical data are presented in Tables 9 and 10. In Figure 14(a), it can be seen that Collector 1 presented practically the same behavior, despite the different radiation conditions. In Figure 14(b) and 14(c) it is possible to verify the temperature losses caused by increasing the tracking period of Collector 2, thus reducing the system's overall thermal efficiency. In Figure 15, better results can be seen for Collector 1 . 
(a) Collector 1

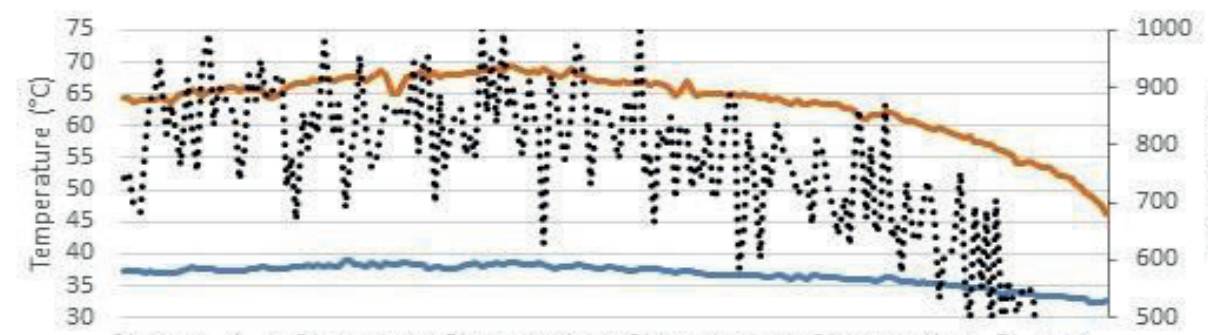

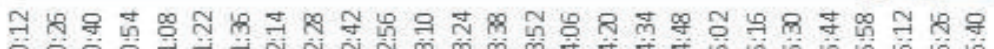

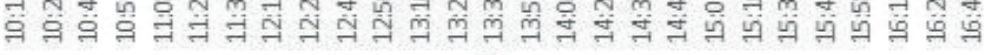
Time Collector 1 - Inlet _ Collector 1 -Outlet $\quad$ C.... Solar Radiation (b) Collector 2

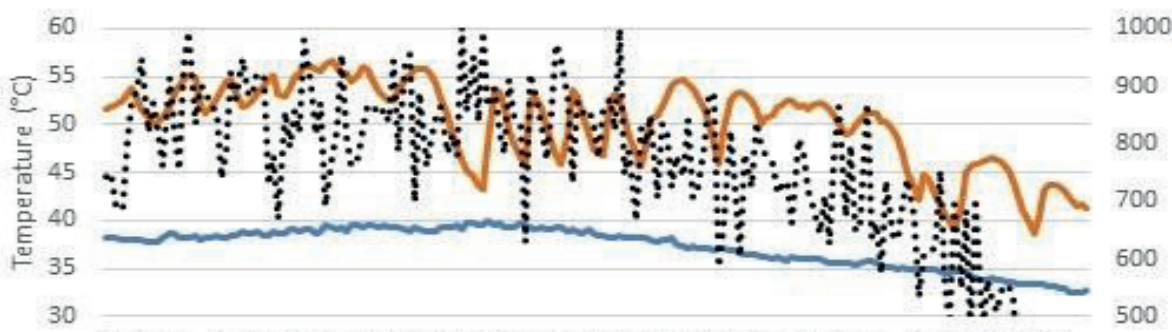

구 Time

Collector 2 - Inlet Collector 2 - Outlet Solar Radiation

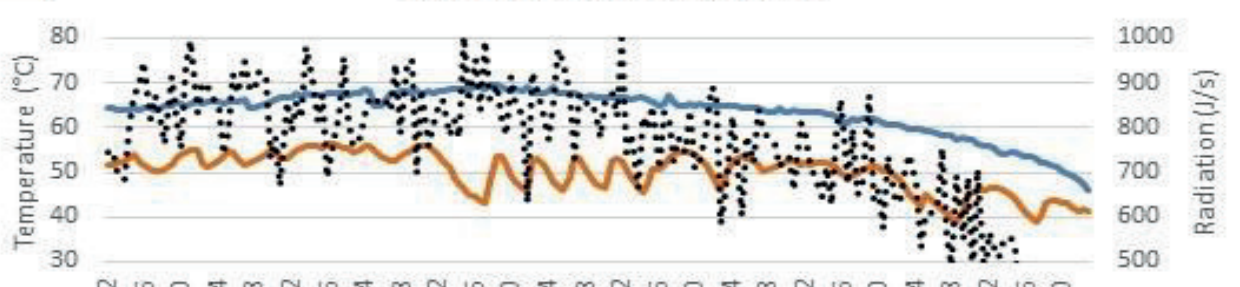

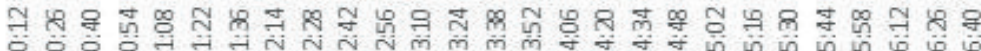

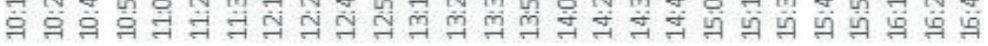

$$
\text { Time }
$$

Sola Radiation

Figure 14. Results of experiment 4: (a) Collector 1 data; (b) Collector 2 data; (c) Comparison of collector outlet temperatures. 


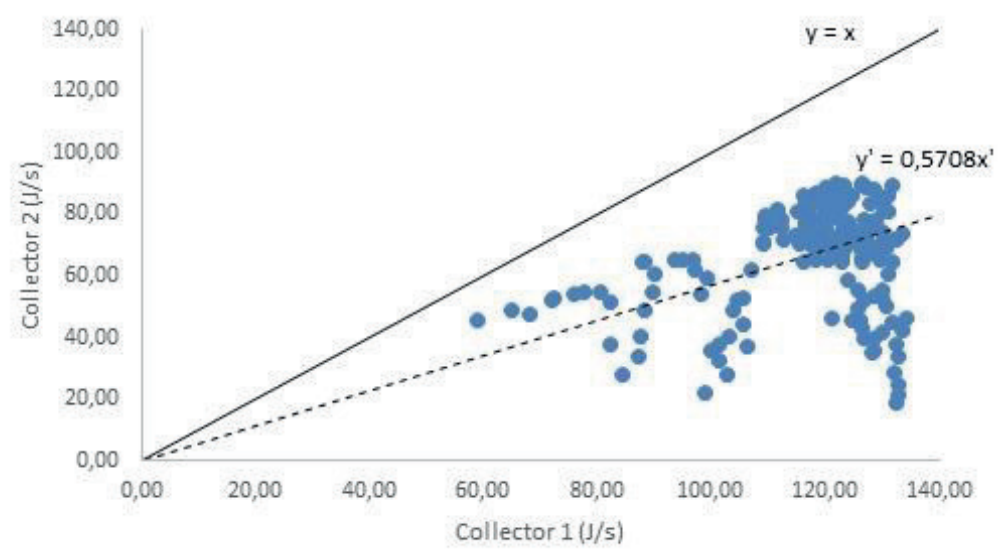

Figure 15. Comparison of absorbed energy results in experiment 4.

Table 9

Statistical data of experiment 4

\begin{tabular}{ccc}
\hline Statistical study & Collector 1 & Collector 2 \\
\hline Average & 116.73 & 67.10 \\
Default error & 1.10 & 1.26 \\
Median & 121.33 & 71.53 \\
Mode & 129.77 & 65.75 \\
Standard deviation & 15.09 & 17.22 \\
Sample variance & 227.60 & 296.56 \\
Kurtosis & 2.39 & -0.24 \\
Asymmetry & -1.63 & -0.80 \\
\hline
\end{tabular}

Table 10

ANOVA of experiment 4

\begin{tabular}{ccccccc}
\hline Variation Source & SQ & gl & MQ & F & value-P & Critical F \\
\hline Between groups & 231543.91 & 1.00 & 231543.91 & 883.49 & 0.00 & 3.87 \\
Within the groups & 98017.45 & 374.00 & 262.08 & & & \\
Total & 329561.36 & 375.00 & & & & \\
\hline
\end{tabular}

In experiment 5, the tracking period of Collector 1 was increased to 5 minutes while Collector 2 remained at 15 minutes. In Figure $16(\mathrm{a})$, it is possible to verify the temperature oscillations caused by the change in rotation time of Collector 1. This caused a decrease in the tube outlet temperature, indicating that Collector
1 presented lower temperatures during the test. Figure 17 shows that there is a higher dispersion of the collectors' absorbed energy, indicating that Collector 1 presented lower temperatures in relation to the previous experiment. The statistical data are presented in Tables 11 and 12. 
(a)

Collector 1
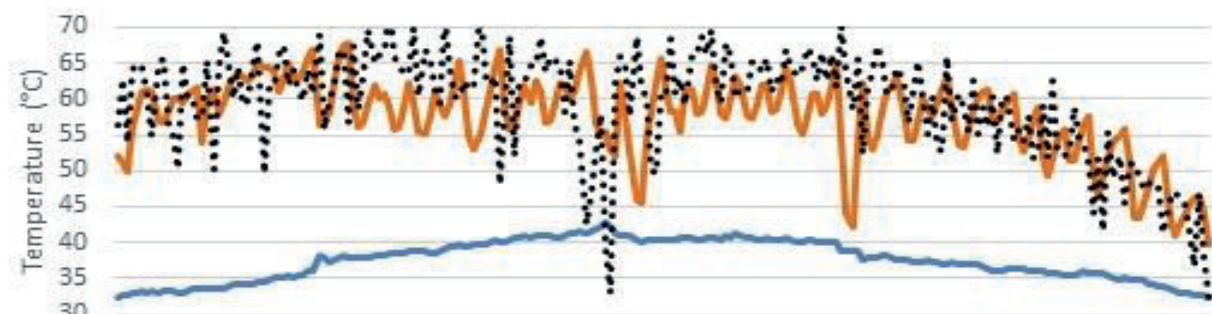

1000

900

800

700

600

500

400

누 200

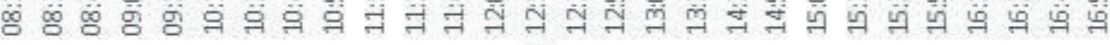
Time

Collector 1 - Inlet $\quad$ Collector 1 -Outlet $\quad \ldots .$. Solar Radiation

(b)

\section{Collector 2}

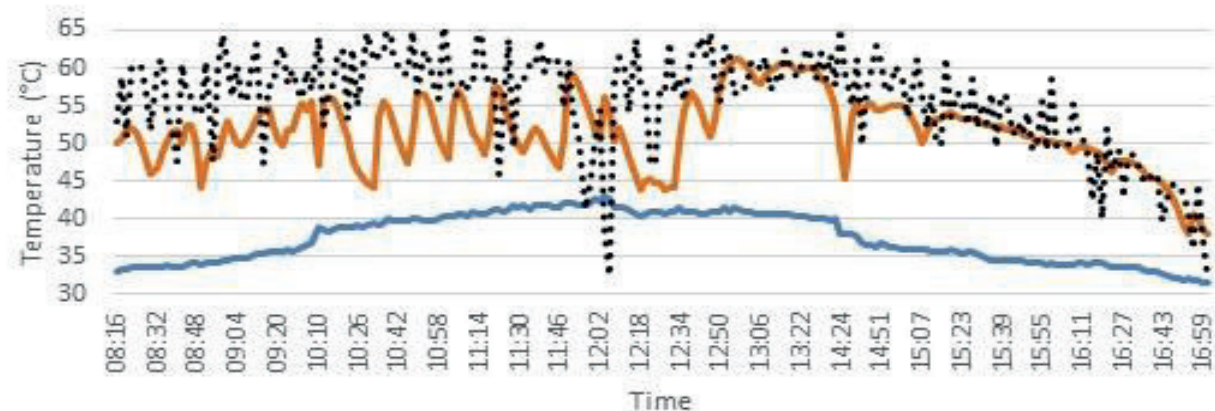

ต 200

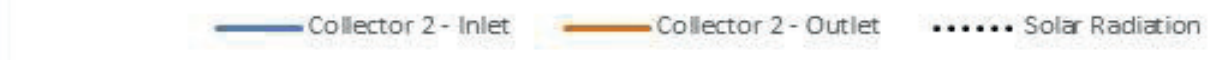

(c) Collector 1 / Collector 2

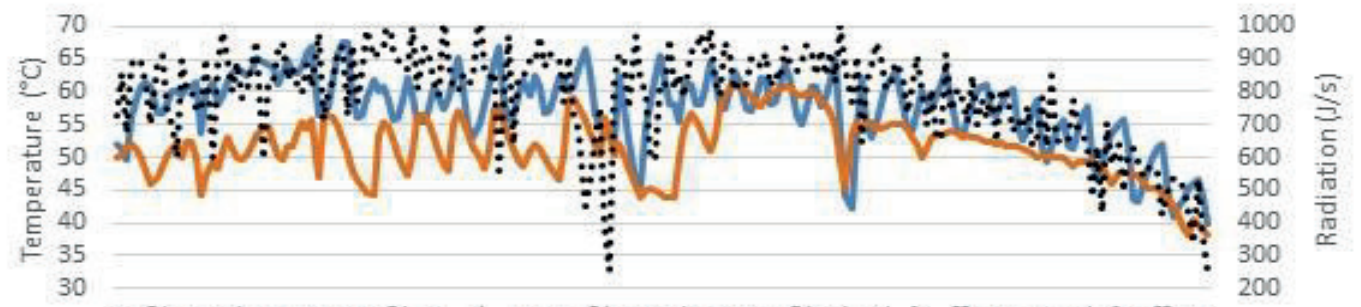

9 m

क Time

Figure 16. Results of experiment 5: (a) Collector 1 data; (b) Collector 2 data; (c) Comparison of collector outlet temperatures. 


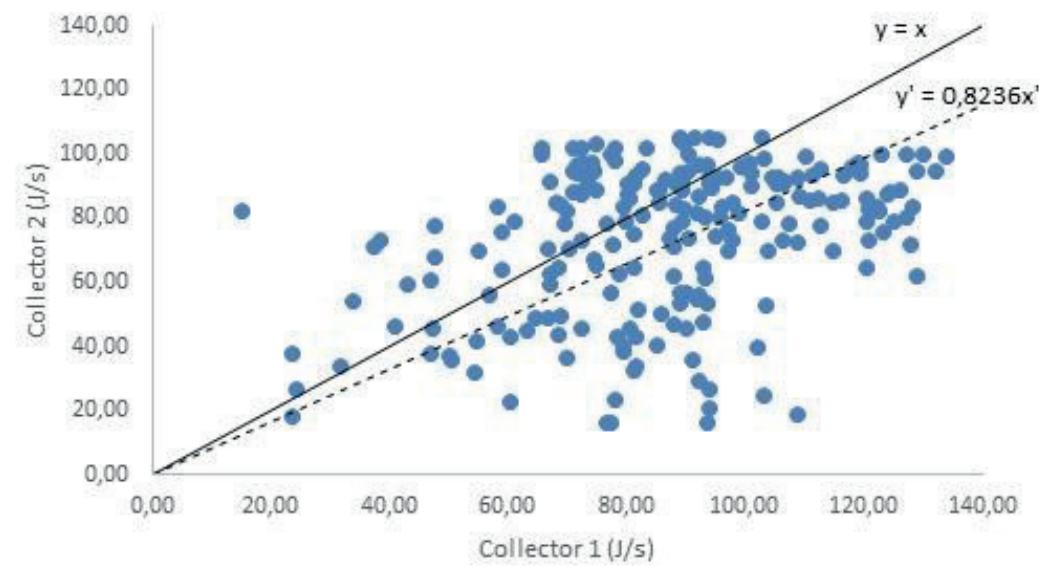

Figure 17. Comparison of absorbed energy results in experiment 5.

Table 11

Statistical data of experiment 5

\begin{tabular}{ccc}
\hline Statistical study & Collector 1 & Collector 2 \\
\hline Average & 86.68 & 74.30 \\
Default error & 1.59 & 1.56 \\
Median & 88.24 & 81.00 \\
Mode & 88.67 & 90.99 \\
Standard deviation & 23.48 & 23.03 \\
Sample variance & 551.28 & 530.15 \\
Kurtosis & 0.15 & -0.38 \\
Asymmetry & -0.32 & -0.79 \\
\hline
\end{tabular}

Table 12

ANOVA of experiment 5

\begin{tabular}{ccccccc}
\hline Variation Source & SQ & gl & MQ & F & value-P & Critical F \\
\hline Between groups & 16725.16 & 1.00 & 16725.16 & 30.93 & 0.00 & 3.86 \\
Within the groups & 234671.17 & 434.00 & 540.72 & & & \\
Total & 251396.33 & 435.00 & & & & \\
\hline
\end{tabular}

Thereby, the tracking time of 1 minute is the best in all cases, taking into account only the amount of energy absorbed. However, it was experimentally observed that this tracking interval is sometimes not enough to cause movement of the collectors. This can be observed by comparing the actuators' clearance angle of approximately $0.5^{\circ}$, according to the manufacturer, with the solar elevation angle variation during 1 minute, which is $0.25^{\circ}$. Therefore, the actuation of the motors does not happen every minute, but approximately every 2 minutes. Thus, the control system drives the motor for rotation, 
and besides, because the clearance angle remains greater than the angle determined for turning the microcontroller algorithm, the system does not rotate and cause an unnecessary waste of energy.

Regarding the 5-minute tracking interval, the motors always rotate the concentrators in the time period, since the solar elevation angle variation, in this case, is $1.25^{\circ}$, always being greater than the motor's clearance angle. By analyzing the acceptance angle of the concentrators used, which is $1.21^{\circ}$, in this way, the absorber tube stays out of the focus for a short period of time.

Thus, the 5-minute interval is presented as an alternative to taking into account the energy consumed by the tracking system for an application requiring lower temperature values. Furthermore, this interval time could be used as an alternative to the 1-minute tracking interval for a better temperature control.
A comparison of the collectors' thermal efficiencies in different time intervals is shown in Figure 18. For the 1-minute tracking interval the average value was around $25.87 \%$; for the 5 -minute tracking interval it was $18.48 \%$; for the 15 -minute tracking interval, $14.80 \%$. The temperature ranges were $45-70{ }^{\circ} \mathrm{C}, 41-68{ }^{\circ} \mathrm{C}$ and $39-62^{\circ} \mathrm{C}$. Despite the small difference between the temperature ranges for these three different tracking intervals, the shortest interval presents a higher average temperature of $63.73{ }^{\circ} \mathrm{C}$, while the other values were $57.9^{\circ} \mathrm{C}$ and $51.88{ }^{\circ} \mathrm{C}$ for the 5 -minute and 15 -minute tracking intervals, respectively.

To reduce the waste of actuators' energy, the tracking interval of 5 minutes is enough for thermotherapy application, reaching almost all temperatures between the lethal values for phytopathogens.

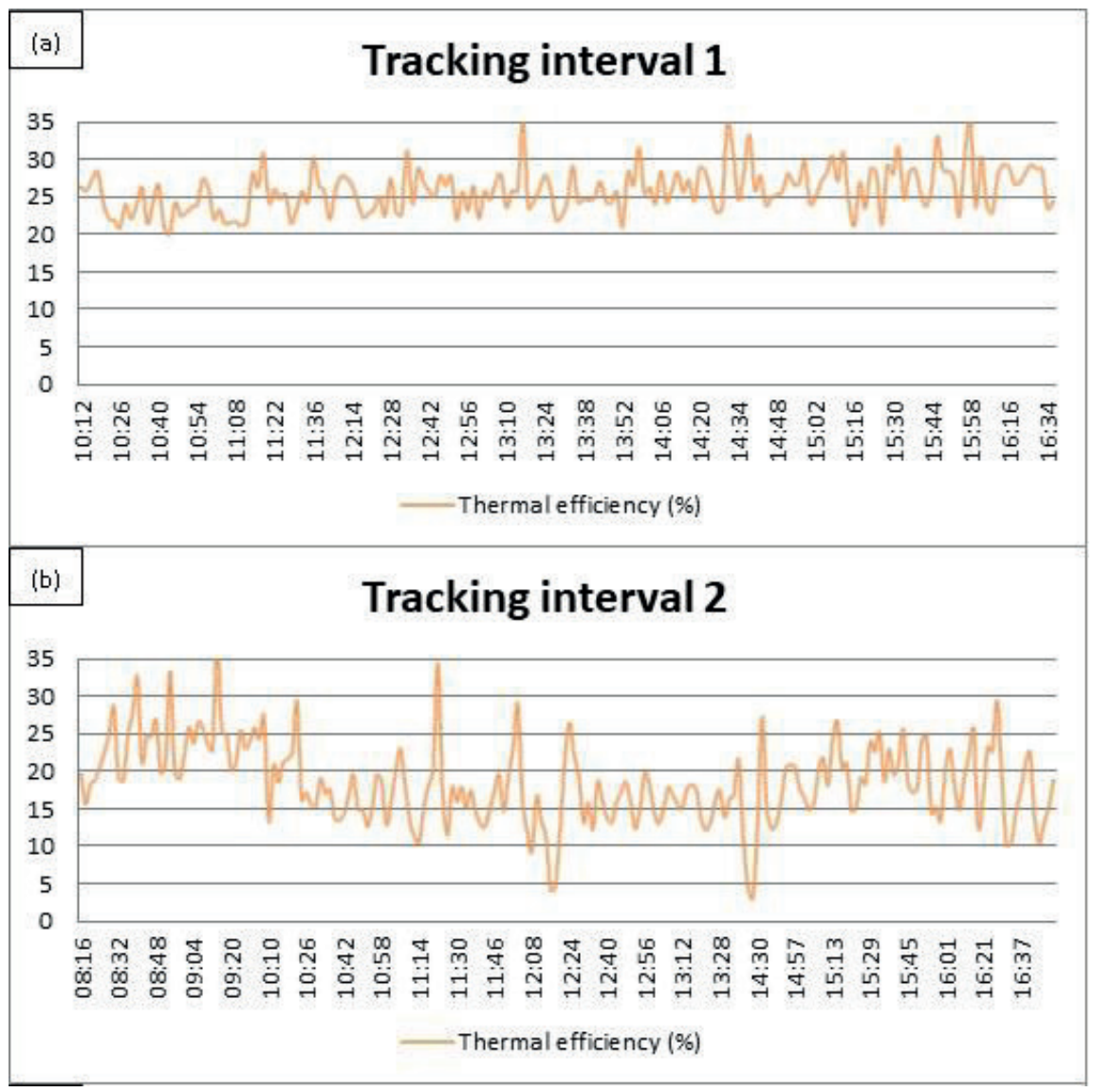




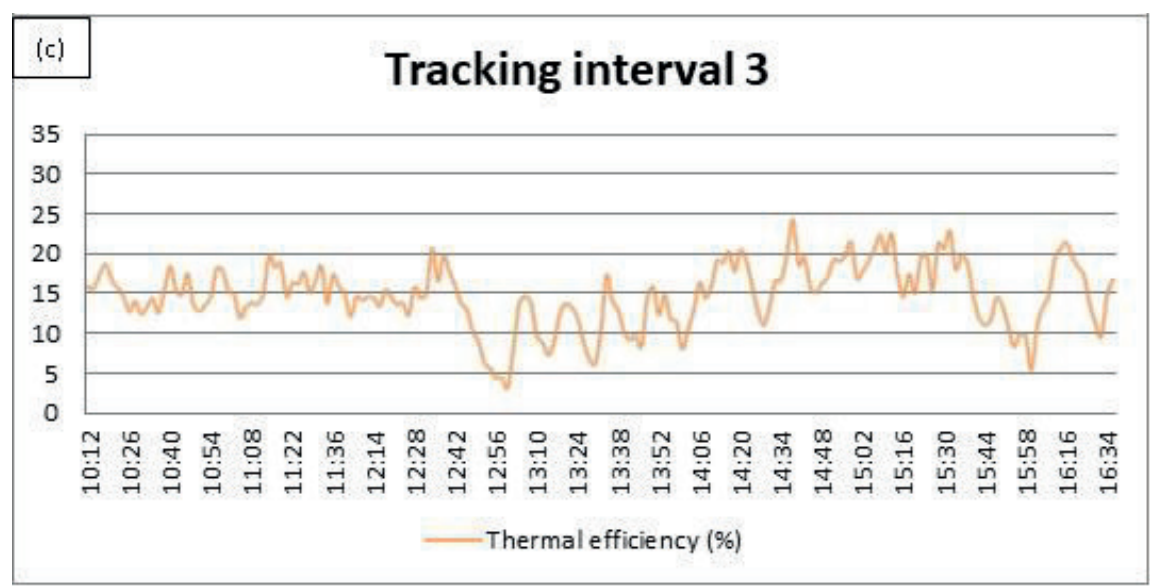

Figure 18. Tracking interval: (a) 1 minute; (b) 5 minutes; (c) 15 minutes.

\section{Conclusion}

Solar thermal energy has been widely used in recent years, both because of the abundance of its resource and also because of technological advances that have made it more financially viable.

This work studied the installation and related improvements ofPTCs foruseinwaterdisinfestationin agricultural areas. It was found that the concentrators' parameters were consistent compared to those on the market, having a concentration rate of 15 suns. The way to improve the collectors' performance was to use a glass tube to reduce convective losses and a steel mirror plate on the reflectors in order to increase the irradiation reflection.

In the experiments, the two collectors were automated, and the best time to rotate them was analyzed, being stipulated as 1, 5 and 15 minutes. System automation has advantages whereas manual tracking requires an operator to be available to rotate the collectors at short time intervals.

Five experiments were carried out:

Performance comparison between the concentrators: The collectors were set to a 15-minute manual tracking interval in order to have a correction factor, for uniform comparison with other tests. Collector 1 presented a slightly superior performance to collector 2 .
Influence of automatic tracking on the system: Collector 1 was automated, while Collector 2 was manually tracked, both at 15-minute intervals. The results showed that the calibration factor used was correct and that the automatic system had similar results to the manual system.

First analysis of different intervals of automatic tracking: Collector 1 was set at a time interval of 1 minute, and Collector 2 at an interval of 5 minutes. Collector 1 provided the best result.

Second analysis of different intervals of automatic tracking: Collector 1 was set at a 1-minute interval and Collector 2 at a 15-minute interval. Collector 1 provided the best result.

Third analysis of different intervals of automatic tracking: Collector 1 was set at a 5-minute interval, and Collector 2 at a 15-minute interval. Collector 1 provided the best result.

Considering only the amount of energy absorbed by the system, the best result was for tracking intervals of 1 minute, as expected. The rotation angle for the 1-minute tracking interval is $0.25^{\circ}$, while for the 5 -minute angle it is $1.25^{\circ}$.

For the 1-minute tracking interval, the PTCs presented a thermal efficiency of $25.87 \%$, with temperatures between 45 and $70{ }^{\circ} \mathrm{C}$ and an average temperature of $63.73{ }^{\circ} \mathrm{C}$. For the 5 -minute tracking 
interval, the thermal efficiency was $18.48 \%$, reaching temperatures between 41 and $68{ }^{\circ} \mathrm{C}$ with an average temperature of $57.9^{\circ} \mathrm{C}$. For the 15 -minute tracking interval, the PTCs presented a thermal efficiency of $14.80 \%$, with temperatures between 39 and $62{ }^{\circ} \mathrm{C}$ and an average temperature of $51.88^{\circ} \mathrm{C}$.

The results obtained with the equipment developed using solar energy as a heat source in the automated heating of water, for these tracking intervals, showed that the system performance is efficient and works in the temperature range for water disinfestation, aiming at the control of phytopathogens to control soil pathogens on small and medium farms. The tracking intervals of 1 and 5 minutes present more values between the lethal temperature range of 45 and $60{ }^{\circ} \mathrm{C}$ for phytopathogens. Thus, for agricultural application, the usage of a tracking interval of 5 minutes could be an option for reducing waste of the system energy.

\section{Acknowledgments}

This work is based on research supported by the Coordenação de Aperfeiçoamento de Pessoal de Nível Superior (CAPES). The support received from the Federal University of Ceará is also duly acknowledged and appreciated.

\section{References}

Abdallah, S. (2004). The effect of using sun tracking systems on the voltage-current characteristics and power generation of flat plate photovoltaics. Energy Conversion and Management, 45,(11-12), 16711679. doi: 10.1016/j.enconman.2003.10.006

Afrin, F., Titirsha, T., Sanjidah, S., Siddique, R. M. \& Rabbani, A. (2013, december). Installing dual axis solar tracker on rooftop to meet the soaring demand of energy for developing countries. Proceedings of the Annual IEEE India Conference (INDICON), Mumbai, Maharashtra India, 2013. Retrieved from https://ieeexplore.ieee.org/document/6726033. doi: 10.1109/INDCON.2013.6726033

Ali, A. S., Zanzinger, Z., Debose, D., \& Stephens, B. (2016). Open Source Building Science Sensors
(OSBSS): A low-cost Arduino-based platform for long-term indoor environmental data collection. Building and Environment, 100, 114-126. doi: 10.1016/j.buildenv.2016.02.010

Barbosa, E. S. (2009). Desenvolvimento de um sistema de controle de baixo custo para rastreamento de concentradores cilíndrico-parabólicos. Dissertação (Mestrado em Engenharia Mecânica) - Departamento de Engenharia Mecânica, Universidade Federal do Ceará, Fortaleza.

Baltas, P., Tortoreli, M., \& Russel, P. E. (1986). Evaluation of power output for fixed and step tracking photovoltaic arrays. Solar Energy, 37(2), 147-163. doi: 10.1016/0038-092X(86)90072-1

Bahlol, H. Y., Sinha, R., Hoheisel, G., Ehsani, R., \& Khot, L. R. (2018). Efficacy evaluation of horticultural oil based thermotherapy for pear psylla management. Crop Protection, 113, 97-103. doi: 10.1016/j. cropro.2018.07.015

Behar, O., Khellaf, A., \& Mohammedi, K. (2015). A novel parabolic trough solar collector model Validation with experimental data and comparison to Engineering Equation Solver (EES). Energy Conversion and Management, 106, 268-281. doi: 10.1016/j.enconman.2015.09.045

Bellos, E., Tzivanidis, C., \& Antonopoulos, K. A. (2017). A detailed working fluid investigation for solar parabolic trough collectors. Applied Thermal Engineering, 114, 374-386. doi: 10.1016/j. applthermaleng.2016.11.201

Bentaher, H., Kaich, H., Ayadi, N., Hmouda, M. B., Maalej, A., \& Lemmer, U. (2013). A simple tracking system to monitor solar PV panels. Energy Conversion and Management, 78, 872-875. doi: 10.1016/j.enconman.2013.09.042

Braga, C. A. S., Armond, G., Tanaka, M. A. S., Ito, M. F., Mesquita, C. M., Maziero, J. V. G.,... Peche, A, $\mathrm{F}^{\mathrm{o}}$. (2001). Sistema automatizado de aquecimento solar para controle de fitopatógenos da água de irrigação. Revista Brasileira de Engenharia Agrícola e Ambiental, 5(2), 327-331. doi: 10.1590/S141543662001000200025

Carvalho, N. M., \& Nakagawa, J. (2012). Sementes: ciência, tecnologia e produção (5a ed.). Jaboticabal: Funep.

Chang, T. P. (2009). Performance study on the east-west oriented single-axis tracked panel. Energy, 3 (10), 1530-1538. doi: 10.1016/j.energy.2009.06.044

Cochrane, V. W. (1958). Physiology of fungi. New York: John Wiley \& Sons Inc. 
Doria, U, Fo . (1999). Introdução à bioestatística: para simples mortais. São Paulo: Negócio Editora.

Erdogan, A., Colpan, C. O., \& Cakici, D. M. (2017). Thermal design and analysis of a shell and tube heat exchanger integrating a geothermal based organic Rankine cycle and parabolic trough solar collectors. Renewable Energy, 109, 372-391. doi: 10.1016/j. renene.2017.03.037

Ghatrehsamani, S., Abdulridha, J., Balafoutis, A., Zhang, X., Ehsani, R., \& Ampatzidis, Y. (2019). Development and evaluation of a mobile thermotherapy technology for in-field treatment of Huanglongbing (HLB) affected trees. Biosystems Engineering, 182, 1-15. doi: 10.1016/j.biosystemseng.2019.03.011

Ghini, R. (2004). Coletor solar para desinfestação de substratos para produção de mudas sadias. Jaguariúna: Embrapa-CNPMA. (Circular Técnica).

Goswami, D. Y., \& Kreith, F. (2008). Energy conversion (1a ed.). Boca Raton: CRC Press, Taylor and Francis Group. (Mechanical engineering series).

Hafez, A. Z., Attia, A. M., Eltwab, H. S., Elkousy, A. O., Afifi, A. A., Abdelhamid, A. G.,... Ismail, I. M. (2018). Design analysis of solar parabolic trough thermal collectors. Renewable and Sustainable Energy Reviews, 82(Part 1), 1215-1260. doi: 10.1016/j.rser.2017.09.010

Huang, B. J., \& Sun, F. S. (2007). Feasibility study of one axis three positions tracking solar PV with low concentration ratio reflector. Energy Conversion and Management, 48(4), 1273-1280. doi: 10.1016/j. enconman.2006.09.020

Jebasingh, V. K., \& Herbert, G. M. J. (2016). A review of solar parabolic trough collector. Renewable and Sustainable Energy Reviews, 54, 1085-1091. doi: 10.1016/j.rser.2015.10.043

Konar, A., \& Mandal, A. K. (1991). Microprocessor based automatic sun tracker. IEE Proceedings $A$ Science, Measurement and Technology, 138(4), 237241. doi: 10.1049/ip-a-3.1991.0032

Li, Z., Liu, X., \& Tang, R. (2010). Optical performance of inclined south-north single-axis tracked solar panels. Energy, 35(6), 2511-2516. doi: 10.1016/j.energy.2010.02.050

Lima, M. C. Fo . (2014). Sistema de rastreamento solar com dois eixos para painéis fotovoltaicos, coletores cônicos, cilíndricos e parabólicos. Trabalho de Conclusão de Curso (Graduação em Engenharia Mecânica) - Departamento de Engenharia Mecânica, Universidade Federal do Ceará, Fortaleza.
Liu, P., Zheng, N., Liu, Z., \& Liu, W. (2019). Thermalhydraulic performance and entropy generation analysis of a parabolic trough receiver with conical strip inserts. Energy Conversion and Management, 179, 30-45. doi: 10.1016/j.enconman.2018.10.057

Macedo-Valencia, J., Ramírez-Ávila, J., Acosta, R., Jaramillo, O. A., \& Aguilar, J. O. (2014). Design, construction and evaluation of parabolic trough collector as demonstrative prototype. Energy Procedia, 57, 989-998. doi: 10.1016/j. egypro.2014.10.082

Malav, S., \& Vadhera, S. (2015, june). Hardware implementation of solar tracking system using a stepper motor. Proceedings of the International Conference on Energy, Power and Environment: Towards Sustainable Growth (ICEPE), Shillong, Meghalaya, India, 2015. Retrieved from (https:// ieeexplore.ieee.org/document/7510065). doi: 10.1109/EPETSG.2015.7510065

Marcos, J., Fº (2005). Fisiologia de sementes de plantas cultivadas. Piracicaba: FEALQ. (Technical report).

Montgomery, D. C., \& Runger, G. C. (2007). Applied statistics and probability for engineers (4th ed.). Hoboken: John Wiley and Sons Ltd. (Computational Science and Engineering Series).

Moraes, E. P. (2012). Seguidor solar de um único eixo inclinado. Trabalho de Conclusão de Curso (Graduação em Engenharia da Computação) - Centro Universitário de Brasília, Brasília.

Mousazadeh, H., Keyhani, A., Javadi, A., Mobli, H., Abrinia, K., \& Sharifi, A. (2009). A review of principle and sun-tracking methods for maximizing solar systems output. Renewable and Sustainable Energy Reviews, 13(8), 1800-1818. doi: 10.1016/j. rser.2009.01.022

Mwesigye, A., \& Meyer, J. P. (2017). Optimal thermal and thermodynamic performance of a solar parabolic trough receiver with different nanofluids and at different concentration ratios. Applied Energy, 193, 393-413. doi: 10.1016/j.apenergy.2017.02.064

Othman, N., Manan, M. I. A., Othman, Z., \& Junid, S. A. M. A. (2013, november). Performance analysis of dual axis solar tracking system. Proceedings of the IEEE International Conferences on Control System, Computing and Engineering (ICCSCE). Mindeb, Malaysia, 2013. Retrieved from https://ieeexplore. ieee.org/document/6719992. doi: 10.1109/ ICCSCE.2013.6719992 
Partel, V., Kakarla, S. C., \& Ampatzidis, Y. (2019). Development and evaluation of a low-cost and smart technology for precision weed management utilizing artificial intelligence. Computers and Electronics in Agriculture, 157, 339-350. doi: 10.1016/j. compag.2018.12.048

Rizvi, A. A., Addoweesh, K., El-Leathy, A., \& Al-Ansary, H. (2014, october). Sun position algorithm for sun tracking applications. Proceedings of the Annual Conference of the IEEE Industrial Electronics Society (IECON), Dallas, Texas, USA, 40. Retrieved from https://ieeexplore.ieee.org/document/7049356. doi: 10.1109/IECON.2014.7049356

Santos, C. M. R., Menezes, N. L. D., \& Vilella, F. A. (2005). Modificações fisiológicas e bioquímicas em sementes de feijão no armazenamento. Revista Brasileira de Sementes, 27(1), 104-114. doi: 10.1590/S0101-31222005000100013
Schneider, C. F., Gusatto, F. C., Malavasi, M. M., Stangarlin, J. R., \& Malavasi, U. C. (2015). Thermotherapy on physiological and health quality of stored jatropha seeds. Semina: Ciências Agrárias, 36(1), 47-56. doi: 10.5433/1679-0359.2015v36n1p47

Suman, S., Khan, M. K., \& Pathak, M. (2015). Performance enhancement of solar collectors: A review. Renewable and Sustainable Energy Reviews, 49, 192-210. doi: 10.1016/j.rser.2015.04.087

Sungur, C. (2009). Multi-axes sun-tracking system with PLC control for photovoltaic panels in Turkey. Renewable Energy, 34(4), 1119-1125. doi: 10.1016/j. renene.2008.06.020

Tanaka, M., Ito, M., Braga, C., \& Armond, G. (2003). Tratamento térmico solar da água para controle de fitopatógenos. Fitopatologia Brasileira, 28(4), 386393. doi: 10.1590/S0100-41582003000400007

Wolf, F. A., \& Wolf, F. T. (1947). The fungi (Vol. I.) New York: John Wiley \& Sons. 